\title{
プラスチックス上のメッキの問題点
}

\section{1. 展望}

プラスチックスにメッキする方法としては, 真空蒸着 法と電気メッキ法が代表的なものである。

真空蒸着法とは，メッキすべき金属を真空中で加熱気 化させ，被メッキ体表面に析出させる方法で，反射鏡な ぞの光学的用途，またはエレクトロニクス工業に括ける 薄膜技術として重要な役割を果している。

プラスチックス素材を対象とする場合には，装飾を目 的にアルミニウム蒸着膜の使われることが多く, 頑具, 雑貨類をはじめ, 自動車の室内部品などに使用され出し たのはそう最近のことではない。

しかし一般に蒸着による金属膜は，1 $1 \mu$ 以下の薄膜で あり, しかも性質は脆く多孔質のため, 耐摩耗性は, ト ップコートとしての透明塗料に依存する。また蒸着アル ミの色調は, 電気メッキによるクロムの色調に比ベて見 劣りすることは明らかである。

このような真空蒸着法のもつ難点を克服して, ここ一, 二年の問に工業的プロセスとして脚光を浴びるようにな ったのがこれから解説しようとする電気メッキ法であ る。

周知のようにこの方法は, 化学メッキを前処理とする あのであるが, 不導体上に化学メッキー電気メッキとい う順序でメッキを行なうことの着想は，それほど新ら しいことではなく，たとえば Brenner'1), Saubestre ${ }^{2)}$, Wein ${ }^{3)}$ 等は, 1950 年台にこの方法についてくわしく論 じている。

その後, プリント回路に打ける through-hole へのメ ッキが，今日のプラスチックスへのメッキの降盛の発端 になったとされているが，決定的な契機となったのは，

やはり ABS 樹脂の出現であろ5。

すなわち，初期のプラスチックス上のメッキ技術で は, 素材とメッキ膜との密着という点に問題が多く, 素 材表面を機械的に荒す工程を前提としたために，通常 の電気メッキに比べて極端に厚いメッキを必要とした。 一つはバフ研摩を可能にするためであり，一つは金属膜 の厚い殼によって素材の变形を強引に抑えるためであ る。

このため量産技術としては，コスト的にも能率的にも

$\begin{array}{llll}\text { 関東学院大学 } & \text { 中 } & \text { 村 } & \text { 実 } \\ \text { 関東学院事業部 } & \text { 斎 } & \text { 藤 } & \text { 囲 }\end{array}$

不满足であり，電気メッキ法によるプラスチックス上の メッキ技術は，一まつの希望を持続しながら伸び脳み状 態にあったといえる。

ABS 樹脂は, よく知られたようにアクリロニトリル 一ブタジンースチレンの共重合ポリマーであり, ポリ アセタール, ポリカーボネートなどとともに新時代の有 機材料として開発され, 特に耐衝撃性を売りものに進出 した樹脂であるが，間るなく真空蒸着や化学メッキなど の表面処理に好適な素材であることが，経験的に認識さ れるようになった。

そしてつい最近になって, 従前のように素材表面を機 械的に 荒す必要のないコンディショナーが確立される と, 通常のメッキ厚サでも, 比較的 moderate な使用還 境ならば一応満足すべき品質が保証されるようになり， 今や従来メッキした金属ダイカストの占めていた用途 を,一部侵食しつつあるといっても過言ではない。

むっとも, 現在プラスチックス上のメッキの対象とな っている部品を見ると，これまでプラスチック成形のま まで使用していた部品を，金属化することによって商品 価値を高めようという傾向が高いが, 技術の普及と進歩 によって, 素材の特色を生かした新分野の用途が開拓さ れよう。

以上の理由から，メッキしたプラスチックスと金属夕゙ イカスト部品を単純に比較することは, 必ずしも妥当で はないが, 同じ形状の部品を両者で成形してメッキ加工 を行なうと仮定したとき，プラスチックスは金属ダイカ ストに比較して次のような利点をもつ。

(i) 軽量である。

（ii）容積当りの素材費, 成形費は一般に安い。

（iii）型面を超仕上げすれば，そのままメッキが可能 であり，研摩工程を省くことができる。

(iv）素材の錆びることはない。

上に示した利点の反面, プラスチックス素材のもつ宿 命的な欠点は, 機械的強度, 耐熱性などに限度のあるこ とである。したがって，少なくとも現状から判断すれば， メッキしたプラスチックスが従来の金属ダイカスト部品 を全面的に代替する可能性は予想されない。

また, メッキ技術そのものも, 金属を素材とする場合 に比較すれば，まだまだ不安定のそしりを免れず，理論 
的に不明の点も多い。

新らしい技術の進歩には, know-how一辺倒の行き方 よりも, know·whyへの地道な追求が強く要望される。

\section{2. メッキ工程の概略と問題点}

プラスチックス上の電気メッキ法として，現在もっと む代表的と思われる工程を次炕示す。

(1) 成形 $\rightarrow$ (2) コンデイショニング $\rightarrow$ (3) 感受性化 $\rightarrow$ (4) 活性化 $\rightarrow$ (5) 化学メッキ $\rightarrow$ (6) 電気銅メッキ $\rightarrow$ （7）光沢ニッケルメッキ $\rightarrow$ (8) クロムメッキ

以下, 主要工程について遂次解説を行ない, 問題点に ついて論じて行きたいと思うが，記述があまりと総花的 になるのをさけるために，素材としては ABS 樹脂を， また化学メッキとしては, 化学銅メッキ攵使用した場合 を中心に論を進めたいと思う。

\section{2-1 コンデイショニング}

素材の種類または表面状態によっては, コンディショ ニングの前後に機械的な表面粗化あるいはアルカリ脱脂 工程を併用する場合もあるが，素材が ABS 樹脂であ り，かつコンディショナーが適切であれば，その必要は ない。

コソディショナーとしては, クロム酸一硫酸系の強酸 化性容液がもっとも有效である。第 1 表に二, 三代表 例を示した。

コソディショニング処理の目的は, 樹脂表面を化学的 にエッチングすることによって微視的に荒し，次工程の 処理液による表面のヌレを確保すること，物理的な密着 を助長することにあるが，素材の種類によっては，明ら かに表面の化学構造の变化が密着に関連していると思わ れる。たとえば，クロム酸一硫酸系のコンディショニン グ効果のもっとも顕著に現われる ABS 樹脂に対して， ブタジェン成分を含まない AS 樹脂では，同一の処理を 行なっても前者注どの効果はなく, 満足な密着はえられ ない。

したがって ABS 樹脂の場合には，二重結合に富むブ タシェン成分がコンディショニング処理によって, 酸化 またはスルホン化をうけ，その結果，表面の activityが

第 1 表 クロム酸一硫酸系コンディショナーの代表例

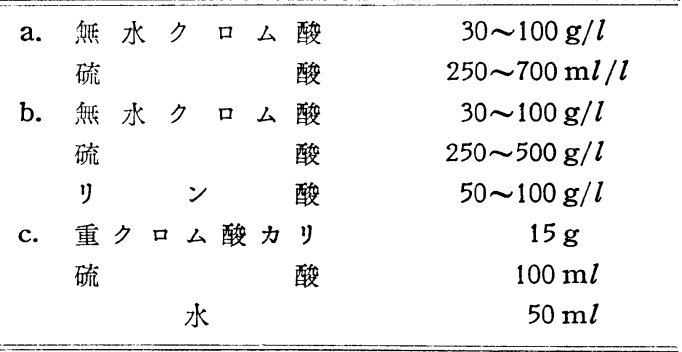

増して金属との結合力が強化すると推定される。

一般にクロム酸一硫酸系のコンディショニングは, $50 \sim 60^{\circ} \mathrm{C}$ で 10〜30 min の処理を必要とするが, 最近ア メリカでは，きわめて短時問の処理ですむ強力なコンデ イショナーが開発されたというニュースもある。

このほか，フェノール樹脂，七ルロース系樹脂，尿素 一ホルマリン樹脂に対して有効なコンディショナーとし

て，次の組成のものが報告されている4)。

$\begin{array}{lll}\text { 硫 } & \text { 酸 } & 7.6 l \\ \text { 硝 } & \text { 酸 } & 3.8 l \\ \text { 塩 } & \text { 酸 } & 0.03 l \\ & \text { 水 } & 1 l\end{array}$

このように，一般に現在使用されているコンディショ ナーは，薬液としてかなり危険度の高いものである。ま た最適操作条件の範囲は比較的せをく，厳密な管理を必 要とする。今後改良の余地はかなりあると思われる。

このほか，接着剤を素材表面に塗布して，金属膜との 密着をえようという試みあなされている5゙。

\section{2-2 感受性化}

コンディショニングの終った素材は, 次に感受性化処 理をらける。

この処理の目的は，還元剤溶液に素材を浸セキして， 表面に還元剤を吸着させることであり，これは次の活性 化処理工程において，触媒としての貴金属イオンを還元 析出させることにつながる。

処理液としては, 一般に塩化第 1 スズの塩酸々性溶液 が使われ，次の組成が標準とされている。

\begin{tabular}{|c|c|}
\hline 塩化第 1 スズ & $10 \mathrm{~g} / l$ \\
\hline 塩酸 & $40 \mathrm{ml} / l$ \\
\hline
\end{tabular}

この溶液中でスズイオンは，単純イオンとしては存在 せず，塩素イオンと結合してクロロ錯イオンを生成して おり，これはこの溶液が，紫外部に極大をもつ吸光特性 を示すことからも推定される。すなわち,

$$
\mathrm{Sn}^{2+}+m \mathrm{Cl}^{-} \rightleftarrows \mathrm{SnCl}_{m}(m-2)-
$$

この溶液中の塩酸濃度が高すぎると, 感受性化処理液 としての機能を失なうのは，錯イオンの状態と関連があ ると思われる。逆に塩酸濃度が不十分であると, 加水分 解を起こし，水酸化物の沈殿を生じやすい。

\section{2-3 活性化}

還元剤としてのスズイオンを表面に吸着した素材を， パラジウム，白金などの貴金属イオンを含む活性化処理 溶液に浸セキすると，次のような酸化還元反応により金 属が析出して，肉眼では見えないていどの薄い触媒層が できる。

$$
\mathrm{Pd}^{2+}+\mathrm{Sn}^{2+} \rightarrow \mathrm{Pd} \downarrow+\mathrm{Sn}^{4+}
$$

な特， $\mathrm{Pd}^{2+}$ の還元は，大部分が化学銅メッキ夜中で 行なわれ， $\mathrm{Sn}^{2+}$ は $\mathrm{Pd}^{2+}$ の固定剤として働くにすぎない 
といら説15功あるが，多かれ少なかれこの段階で上式が 成立するはずである。

活性化処理液としては, 次の塩化パラジウム溶液がも っとも普及している。

$$
\begin{aligned}
& \text { 塩化パラジゥム } \quad 0.2 \sim 1 \mathrm{~g} / l \\
& \text { 塩 酸 } 5 \mathrm{ml} / l
\end{aligned}
$$

ホルマリンを還元剤とする化学銅メッキ夜に対して は, Pd のほかに Pt, Au, Ag などが触媒として有効であ る。もちろん析出した銅そのものも触媒として働く。

一般飞化学メッキに打ける触媒作用の概念は, 単なる 不均一触媒反応と混同されているが,最近著者の一人は, ホルマリンを還元凨とする化学銅メッキについて，電気 化学的方法による一連の研究6) 9) を行ない, 化学銅メッ キの反応が，局部的なアノード電流抢よびカソード電流 による電気化学反応であることを実証した。

またこの場合の触媒作用は, 明らかに electrocataly$\mathrm{sis}^{10)}$ 飞属するものであり, 触媒作用の対象となる反応 は, 主としてホルマリンの陽極酸化反応である。

すなわち, ホルマリンのアルカリ性水溶液を金属電極 上で陽極酸化すると，次のいずれかの反応によってギ酸 イオンを生じる。

(1) $\mathrm{CH}_{2} \mathrm{O}+3 \mathrm{OH}^{-} \rightleftarrows \mathrm{HCOO}^{-}+2 \mathrm{H}_{2} \mathrm{O}+2 e$

$$
\Delta G_{1}^{0}=-49.6 \mathrm{cal} / \mathrm{mol}
$$

(2) $2 \mathrm{CH}_{2} \mathrm{O}+4 \mathrm{OH}^{-} \rightleftarrows 2 \mathrm{HCOO}^{-}+2 \mathrm{H}_{2} \mathrm{O}+\mathrm{H}_{2} \uparrow+2 e$

$$
\Delta G_{2}^{0}=-61.0 \mathrm{cal} / \mathrm{mol}
$$

それぞれの反応について，熱力学的データから得られ る $\Delta G^{0}$ より標準酸化還元電位を計算すると, 次の值を 得る。

$$
E_{1}^{0}=-1.07 \mathrm{~V}, \quad E_{2}^{0}=-1.30 \mathrm{~V} \quad \text { (vs. NHE) }
$$

しかし，一般に有機化合物の電極反応は不可这性の高 いものであり，反応速度は電極の種類によって大きく影 響されるから，上に示した平衡論的数做は実用上ほとん

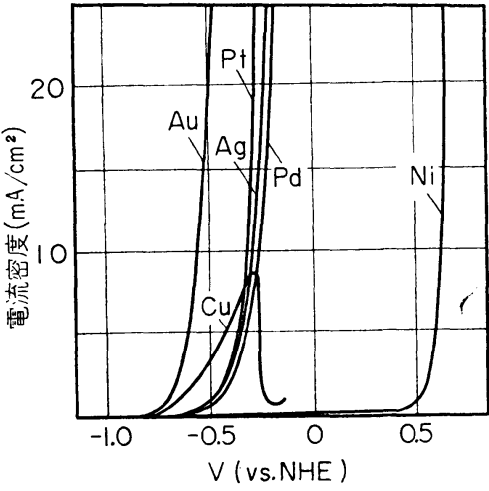

（䉓解液: $\mathrm{n}-\mathrm{NaOH}+0.25 \mathrm{M} \mathrm{CH}_{2} \mathrm{O}$ )

第1図各種電極によるホルマリンの陽 極酸化電流一電位曲線, $20^{\circ} \mathrm{C}$
ぞ役に立たな

い。

たとえば， 同一のアルカ リ性ホルマリ 溶液につい て, 電極材料 の種類とアノ 一ド分極特性 との関係をし らべてみる と，第1図の ような結果が 得られた ${ }^{7) 。 ~}$ 同図に颃い
て, $\mathrm{Au}, \mathrm{Ag}, \mathrm{Pt}, \mathrm{Pd}$ では著るしい分極電流が流れる が，曲線の立上りの電位は計算値よりはるかに貴方向に ずれており，むしろこの $\mathrm{pH}$ に拈ける水素電極電位に 近い。

$\mathrm{Cu}$ 電極でも同様であるが，前者に比べて限界電流が 小さく, この反応に対する触媒能が比較的小さいことを 示している。

また Ni を電極とする場合には，ホルマリンの陽極酸 化に必要な 過電圧が極端に大きく，この反応に対して $\mathrm{Ni}$ が触媒となりえないことを実証している。

このほか, 従来化学銅メッキに打けるホルマリンの酸 化反応として，(1) と (2) の反応式を混同している傾向が 見られるが，第 1 図のアノード電流に伴なって水素ガス の発生が顕著に認められるのは $\mathrm{Au}, \mathrm{Ag}, \mathrm{Cu}$ 電極にか ぎられ，Pt，Pd，Ni などの電極では，(1)の反応が主 体であることが確認された。

しかも，ホルマリソを陽極酸化するとさに，電極の種 類によって上記二つの経路があるといら事実は，すでに 今から 40 年以前に E. Müller ${ }^{12)}$ らによって指摘されて いるのである。

したがって実際作業において，パラジウム溶液により 活性化処理を終った素材表面を化学銅メッキ溶液に入れ ると，まず(1) の酸化反応によってパラジウム上飞銅の 析出反応が起こり，表面が析出した銅によってカバーさ れると，(2) 式にしたがって水素ガスの発生をともない ながら化学銅メッキの反応が進行する。このときのカン 一ド反応は，後述する (5) である。

いずれにせよ，ホルマリンの陽極酸化反応は溶液中の $\mathrm{OH}^{-}$濃度に大きく依存するから， $\mathrm{pH}$ を下げすぎると， 初期の $\mathrm{Cu}$ 析出反応は不利になる。

また第 1 図の結果から，Ag はコストも安く有効な触 媒になりらることが予想されるが，これについては小西 の報告 ${ }^{13)}$ がある。

\section{2-4 化学銅メッキ}

プラスチッチスへのメッキが工業化される以前の化学 銅メッキ液は，かなり濃厚な改良 Fehling溶液であり， 安定度に乏しく，寿命のきわめて短かいものであった。

実用的な化学銅メッキ液として最初に Saubestre ${ }^{2)} の$ 提案したのは，次のような組成のものである。
A. 口ッセル塩
$170 \mathrm{~g} / \mathrm{l}$
カセイソータ
$50 \mathrm{~g} / l$
硫 酸 銅
$30 \mathrm{~g} / l$
Versene-T
$20 \mathrm{ml} / l$

B. ホルマリン (37\%)

（A 5 容と B 1 容を使用直前に混合する）

しかしこれは主としてプリント回路の through-hole へのメッキを目的に開発されたもので，析出速度は十分 
(25 $\mu / \mathrm{h}$ を報告されている) で方るが，少なくとも著者 らの実験では，この組成の化学銅メッキ液は，1 バッ 処理で分解を起こしてしまうほど安定度に乏しいるので あって，量産用としては不適当である。

最近では，さらに稀薄な溶液が使用されている ${ }^{14) 。 ~}$

周知のように, 現在の化学銅メッキ液の母体となって いる Fehling 溶液は，糖類ないしアルデヒド類の検出 に使われる試薬として古くから有名である。

ホルムアルデヒドと Fehling溶液との反応は，次のよ 丂な亜酸化銅の生成反応として表わされる。

(3) $2 \mathrm{Cu}^{2+}+5 \mathrm{OH}^{-}+\mathrm{CH}_{2} \mathrm{O} \rightarrow \mathrm{Cu}_{2} \mathrm{O}+\mathrm{HCOO}^{-}+3 \mathrm{H}_{2} \mathrm{O}$

この反応は, 当然加熱によって促進されるが, 高濃度 に执いては常温でも進行しやすい。

不安定な化学メッキに括ける自然分解反応は (3) 式に よるもので, 生成した $\mathrm{Cu}_{2} \mathrm{O}$ 上ではさらに次のような反 応が起こる。

(4) $\mathrm{Cu}_{2} \mathrm{O}+2 \mathrm{CH}_{2} \mathrm{O}+2 \mathrm{OH}^{-}$

$$
\rightarrow 2 \mathrm{Cu}+\mathrm{H}_{2}+2 \mathrm{HCOO}^{-}+\mathrm{H}_{2} \mathrm{O}
$$

(4) の反応は, 著者らの考炕よれば, $\mathrm{Cu}_{2} \mathrm{O}$ 表面に部 分的に存在する $\mathrm{Cu}$ 面が (2) の酸化反応の触媒となり, $\mathrm{Cu}_{2} \mathrm{O}$ を電気化学的に還元するという Müller の説 ${ }^{12)}$ 支持したい。

このようにして容器壁に沈殿した $\mathrm{Cu}$ 核上では, 化学 メッキと同様の反応が起こって, 溶液の 分解を促進す る。後述するように, $\mathrm{Cu}_{2} \mathrm{O}$ は (2) の反応に対して不活性 である。

したがって理想的な化学銅メッキ液とは, (3)の均一相 反応が起こりにくく，被メッキ体表面上にのみ (2)，(5) による電気化学触媒反応があるていどの速度で起こり 5 るような溶液に他ならない。

いま，次のような低速度ではあるが安定な化学銅メッ
キ夜について，白金上に化学銅メッキを行ならとする。

$\begin{array}{ll}\text { 硫酸 銅 } & 0.02 \mathrm{M} \\ \text { ロッセル塩 } & 0.1 \mathrm{M} \\ \text { 炭酸ソーダ } & 0.1 \mathrm{M} \\ \text { カセイソーダ } & \mathrm{pH} 12.0 \\ \text { ホルマリン } & 0.5 \mathrm{M} \\ \text { 温 度 } & 25^{\circ} \mathrm{C}\end{array}$

析出反応が定常状態に達したときの，銅メッキ白金の 自然電極電位は第 2 図 $\mathrm{O}$ 点江相当し，むちろ几外部電流 はゼロである。そこで，別の対極と銅メッキ白金との間 に外部電圧を加え, 電位走查法によって電極の電位を貴 方向あるいは卑方向に変化させると，戝の太線で描いた いわゆる外部分極曲線が光られる。

次にまったく同じ組成の溶液から， $\mathrm{Cu}^{2+}$ イオンのみ をとり除いた溶液について $E-I$ 曲線を求めると，曲線 (a)がえられる。これは明らかに，(3)式のホルマリンの 酸化反応による電流である。

曲線 $\mathrm{a}$ で示した電流は，P点の直前から急に減少する が，これは $\mathrm{P}$ 点を前後江電極表面に $\mathrm{Cu}_{2} \mathrm{O}$ が生成し，こ れによってホルマリンの 酸化反応が停止するからであ る。すなわち点線で示した曲線は，同一 $\mathrm{pH}$ の溶液中で の $\mathrm{Cu}$ の溶解特性を示するので, $\mathrm{P}$ 点が次の $\mathrm{Cu}_{2} \mathrm{O}$ 生成 電流によるピークであることが，熱力学的考察により確 認7)された。

(4) $2 \mathrm{Cu}+\mathrm{H}_{2} \mathrm{O} \rightarrow \mathrm{Cu}_{2} \mathrm{O}+2 \mathrm{H}^{+}+2 e$

また曲線 (b)は，実测された曲線 $\mathrm{M}$ 招よび (a) より予 想される $\mathrm{Cu}$ 析出反応によるカソード電流で, 次のよう に表わすことができる8)。

(5) $\mathrm{Cu}(\mathrm{OH})_{2}(\text { Tart })^{2-}+2 e \rightarrow \mathrm{Cu}+2 \mathrm{OH}^{-}+(\text {Tart })^{2-}$ ただし上式で (Tart) ${ }^{2-}$ は酒石酸イオンを表わす。 化学銅メッキの 反応は $O$ 点に相当する電位で行なわ

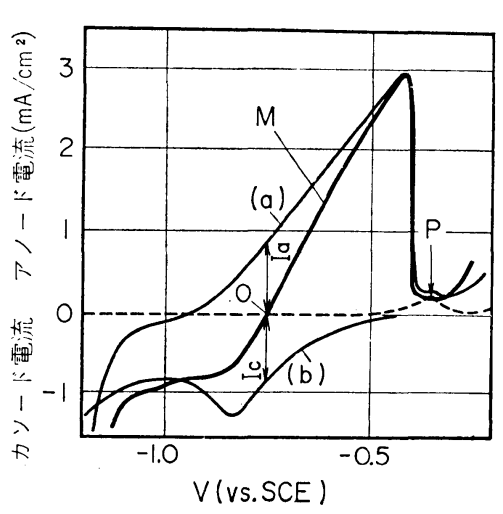

（説明は本文参照）

第 2 図化学銅メッキ液に括ける外 部分極曲線（太線）

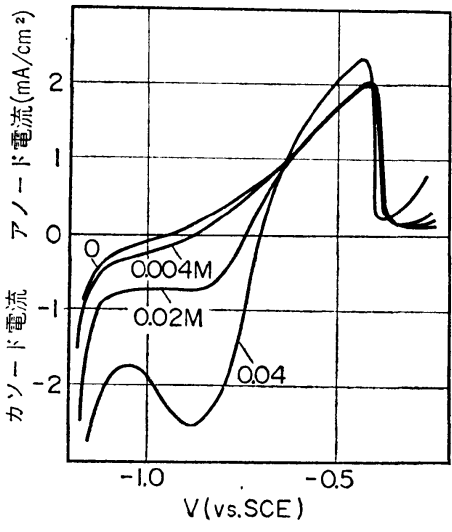

固定条件： $\mathrm{pH} 12.0, \mathrm{Na}_{2} \mathrm{CO}_{3} 0.1 \mathrm{M}$ $\mathrm{KNaT} 4 \mathrm{aq} / \mathrm{CuSO}_{4} 5 \mathrm{aq}=5$ ( $\mathrm{mol}$ 比)

第 3 図硫酸銅浢度を変化させたと きの外部分極曲線, $25^{\circ} \mathrm{C}$

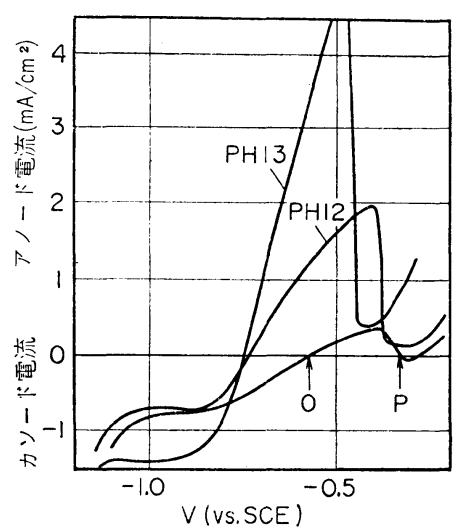

固定条件： $\mathrm{CuSO}_{4} 5 \mathrm{aq} 0.02 \mathrm{M}$,

$\mathrm{KNaT} 4 \mathrm{aq} 0.1 \mathrm{M}, \mathrm{Na}_{2} \mathrm{CO}_{3} 0.1 \mathrm{M}$

第4図 $\mathrm{pH}$ を変化させたときの外 部分極曲線, $25^{\circ} \mathrm{C}$ 
れこの電位では次の関係が成立している。

$$
I_{a}=-I_{c} \quad\left|I_{a}\right|=\left|I_{c}\right|=I_{0}
$$

$I_{0}$ は, 混成電位に拈ける交換電流密度とよばれるもの で, 別に重量法によって求めたメッキ速度を, 電流值に 換算した値とほぼ一致する。

硫酸銅として加える銅イオン濃度を変化させたときの 外部分極曲線を第 3 図に示したが，これは第 2 図のモデ ルを理解するう党に役立つであろう。第 4 図には, $\mathrm{pH}$ と 外部分極曲線の関係を示した。実際には $\mathrm{pH} 11.0$ では, 白金上に黄カッ色の皮膜を生じるだけで，反応は進行し ない。これは $\mathrm{pH} 11.0$ では銅メッキ面の電位は, O点 よりも $\mathrm{P}$ 点に落ちつきやすいからである。つまり, 腐食 反応に括ける不働態化現象によく似ている。

また, 空気カクハンを行なうことによって, 溶液の安 定度が増すという事実が経験的に知られている ${ }^{15)}$ 。著者 らの実験では，単に溶液を機械的にカクハソするだけで も同様の効果が認められた。

ここでのくわしい説明は省略するが，カクハンの効果 は溶存酸素の拡散電流の増大, 寸なわち全体のカソード 電流の増大を意味し, 上述のような不働態化現象を起こ しやすい9)。

そのほか, 種々の添加剤の効果, キレート剤の効果な ども電気化学機構の立場より矛盾なく説明することが可 能である9)。

\section{2-5 化学ニッケルメッキ}

化学ニッケルメッキは, 化学銅メッキに比較すればす でに完成された技術である。プラスチックス上のメッキ のための前処理法としては, コスト高であること, 操作 温度が高く素材の変形を招きやすいことなどの欠点があ るため，一時的に化学銅メッキに圧倒されたかたちであ ったが，化学銅メッキに関する実際経験から，上うやく その限界が見えはじめたため，ふたたび見直されるにい たった。

化学銅メッキの持つ重要な欠点とは, 次の二点であろ 3 。

(i ) 析出速度に限界がある。

（ii）化学銅メッキの表面は，変色，シミなどを起こ しやすく，次の電気メッキ工程までの中間処理が むずかしい。

一方，化学ニッケルメッキにる前述したような欠点が あるが，これはメッキ液組成を改良することにより解決 できる性質のものである。

化学ニッケルメッキの組成に関しては，いままで多数 が報告されているが, 大別して（a）酸性浴と（b) アルカ リ性浴に区別することができ，次に代表的例を示す。

(a) 酸性浴

$$
\text { 塩化ニッケル } 0.1 \mathrm{M}
$$

$$
\begin{array}{cl}
\text { 次亜リン酸ソーダ } & 0.25 \mathrm{M} \\
\text { コハク酸 } & 0.1 \mathrm{M} \\
\mathrm{pH} & 5
\end{array}
$$

温度 $\quad 95 \sim 98^{\circ} \mathrm{C}$

(b) アルカリ性浴

$0.1 \mathrm{M}$

硫酸ニッケル $0.25 \mathrm{M}$

次亜リン酸ソーダ

$0.2 \mathrm{M}$

ピロリン酸ソーダ

$\mathrm{pH} 10.5$

アソモニア

$70^{\circ} \mathrm{C}$

化学ニッケルメッキのメカニズムについては今日まで 定説がなく, Gutzeit ${ }^{16)}$ の水素還元説が本命とされてい るが, 最近 West ${ }^{17)}$ はその著畫の中で, 次のような電気 化学機構を提起している。

すなわち，まず第一段反応として次悪りン酸イオンの 接触脱水素反応が起こる。

(6) $\mathrm{H}_{2} \mathrm{PO}_{2}^{-} \rightarrow 2 \mathrm{H}+\mathrm{PO}_{2}^{-}$

これに続いて, 次のような電気化学反応が起こる。

(7) アノード反応 $\mathrm{H} \rightarrow \mathrm{H}^{+}+e$

(8) カソード反応 $\mathrm{Ni}_{\mathrm{aq}}^{2+}+2 e \rightarrow \mathrm{Ni}$

$$
\text { または Ni-complex }+2 e \rightarrow \mathrm{Ni}
$$

(7) 式から推察されるように, 反応速度は $\mathrm{OH}^{-}$濃度に 依存し, 高 $\mathrm{pH}$ ほど有利である。ところがよく知られた ように, $\mathrm{Ni}^{2+}$ はアルカリ性で $\mathrm{Ni}(\mathrm{OH})_{2}$ の沈殿を生じや すく, 強アルカリ性では，錯体を作って安定に存在する ことがむずかしい。

このため, 従来は酸性浴を高温で操作する方法が工業 的に多く採用されてきた。しかし，プラスチック上のメ ッキの前処理として使用する場合には, 薄いメッキが目 的であるから，メッキ速度にそれほど執着する必要はな

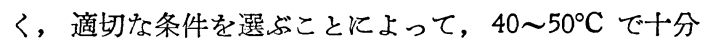
使用できる化学ニッケルメッキ液を作ることが可能であ る。またコストの点も，安定な溶液を作ることによって 解決されよう。

\section{2-6 電気メッキ}

以上にのベた化学メッキにより, 素材表面に電導膜が 付与されてしまえば, あとは通常の金属上のメッキとま ったく同様に電気メッキが行なえるはずであるが，素材 がプラスチックスであるがゆえの特殊な問題が二，三あ り,これらについて簡単にのべる。

最終乙程にクロムメッキを仮定した場合に， $\mathrm{Cu}-\mathrm{Ni}$ $\mathrm{Cr}$ とすべきか， $\mathrm{Ni}-\mathrm{Cr}$ とすべきかという問題があるが， 要はメッキ膜の ductility の問題であり，多かれ少なか れ予想される素材の収縮膨脹によって割レを生じる心配 がなければよい。この場合，耐食性の問題は除外して考 党るべきであろう。

現状では, 一般に光沢硫酸銅メッキ $\rightarrow$ 光沢ニッケル メッキの順序が採用され，その厚サ比は $2: 1$ ないし 
3:1 が理想的とされている。これはいうまでもなく，延 性の高い銅メッキの比率を增して, 割レの生成を極力防 ぐためである。

酸性の硫酸銅浴のほかに, シアン化銅, ピロリン酸銅 浴の使用が考えられるが，これは，素材とメッキ膜との 密着に悪影響を及ほすすこが経験的に知られている。

光沢硫酸メッキに打忷間題は, 優れた光沢剤の種類 が少ないことと，アノードからのスライムをいかに防ぐ かにある。わが国では, 戦後シアン化銅一辺倒にすぎた ために，光沢硫酸銅浴に関する研究ないしは経験の不足 が妙なところに現われたといえる。

前にのべたように，耐食性の問題をほとんど無視でき るとすれば,メッキ厚サは十分な耐摩耗性を支えるてい どで，金属素材の場合ほど神経質になることはないと予 想される。しかし，金属素材とちがってプラスチックス 素材の場合には, メッキ膜が素材の機械的強度をいくぶ ん補なうという意味もあり,また総体的な耐熱耐寒性は, メッキ膜の厚いほど向上するから，コストと能率に影響 しないていどに十分なメッキ厚サを確保すべきである。

\section{3.むす び}

プラスチックス上のメッキ技術は, 歴史が浅く経験に そしいために，今後どのような発展をとげるかについて 予渭することは困難である。

したがって著者らは, あえて本質的な問題を選んで重 点的に述ベたつもりである。

このほか, スプレーによる化学メッキ法, 製品の試験 法, 製品のデザインと成形の問題, ABS 樹脂以外の素 材の処理方法など，いろいろ書きたりなかった点がある
が,これらについては他を参照されたい。

\section{文献}

(1) A. Brenner, Metal Finishing, 52, No. 11, 68 (1954); No. 12, 61 (1954)

(2) E. B. Saubestre, Technical Proceeding of AES, 46, 264 (1959)

(3) S. Wein, "Metalizing Non-Conductors", Metals and Plastics Publication Inc. (1954)

(4) H. Narcus, Trans. Electrochem. Soc., 88, 371 (1945)

(5) E. B. Saubestre, Sylvania Technologist, 12, No. 1, 6 (1959)

（6）斉藤 囲, 電気化学協会第 32 大会講演要旨集 (1965)

（7）斉藤 囲，金属表面技術，16，No. 7 (1965)

（8）斎藤囲, 金属表面技術, 投稿中

（9）㐬藤 囲，金属表面技術，投稿予定

(10) J. O’M. Bockris, “Modern Aspects of Electrochemistry No. 3", p. 347, Butterwoths(1964) G. Charlot, "Electrochemical Reactions" p. 283, Elsevier (1962)

(11) Latimer, "Oxidation Potentials", PrenticeHall (1960)

(12) E. Müller, Annalen der Chemie, 420, 241 (1920); E.Müller and S.Takegami, Z. Elektrochemie, 34, 704 (1928) ; E. Müller, ibid., 29, 264 (1923)

（13）小西三郎，金属表面技術，16，No. 3 (1965)

(14) W. Goldie, Plating, 51, No. 11 (1964)

(15) M.P.Agens, U.S.P. 2,938,805 (1960)

(16) G. Gutzeit, "Symposium on Electroless Nickel Plating", ASTM (1959)

(17) J. M. West, "Electrodeposition \& Corrosion Processes" Van Nostrand (1965)

\section{第 3 回理エ学における同位元素研究発表会}

\section{- 論 文 募 集 ……}

共 催 金属表面技術協会, 日本放射性同位元素協会注加 40 学協会

期 日 昭和 41 年 4 月 19 21日（火木） 場 所東京大学

本会では関倸学協会との共催にて標記研究会を開くことになりました。この研究発表会の目的は, 異なった専門分 野の研究者が一堂に会し，同位元素拈よび放射線の利用の技術を中心とした研究打よびその技術の基礎となる研究の 発表と討論を行ない，各専門分野間の知識と技術の交流を図ろらとするものです。

論文内容（前号参照）

発表時間 1 件 15 分以内

申込締切昭和 41 年 1 月 31 日 (月) 必着

発表申込ならびに詳細については,理工学に拈ける同位元素研究発表会運営委員会(東京都文京区駒込上富士前町31 理研内 日本放射性同位元素協会気付) あて和問合せ下さい。

\section{Institute of Metal Finishing の 1966年年次大会}

Institute of Metal Finishing (英国金属表面技術協会)の年次大会は, 1966年5月3日～ 7 日，英国 Torquay て 開かれます。詳紐は Honorary Secretary, Institute of Metal Finishing, 178, Goswell Road,London, E.C.I. あ て特問合せ下さい。 